\title{
EFFECT OF TRANSFORMATIONAL LEADERSHIP STYLE TO IN-ROLE PERFORMANCE THROUGH ORGANIZATION POLITICS (BUMN OBSERVATION IN MAKASSAR CITY)
}

\author{
Muhammad Idrus Taba \\ Graduate School of Economics \\ Hasanuddin University, Makassar \\ South Sulawesi, Indonesia \\ Muhammad Sobarsyah \\ Graduate School of Economics \\ Hasanuddin University, Makassar \\ South Sulawesi, Indonesia
}

\begin{abstract}
This study examines the influence of transformational leadership on in-role performance through organizational politics. The sample of the research is the employees of State-Owned Enterprises (SOEs) in the form of state-owned enterprises who have worked for at least one year. The sample size is 200 people. The analysis method uses Structural Equation Modeling (SEM). The result of this research shows that transformational leadership has a positive and significant effect on organizational politics, organizational politics have the positive and significant influence on in-role performance and transformational leadership has a positive and significant impact on in-role performance through organizational politics.
\end{abstract}

Keynote: Transformational leadership, in-role performance, and organizational politics

\section{INTRODUCTION}

Leadership is considered as a factor that has a major influence on organizational performance, managers, and employees (Wang et al., 2005). Effective leadership styles in democratic or autocratic, social or target oriented perspectives, etc. are often associated with various aspects of organizational outcomes (Blake and Mouton, 1964; Lewin et al., 1939). Bass Theory (1993); Burns (1978) explains that transformational leadership has a strong positive effect on employee attitudes toward work, the work environment and ultimately affects overall performance.

Organizational politics, often put in a position as an important performance antecedent of employees (Adams et al., 2002; Allen et al., 1979; Ferris and Kacmar, 1992; Gandz and Murray, 1980). Several previous studies have linked organizational politics to the theory of justice, equity, and workplace justice (Ferris and Kacmar, 1992; Vigoda-Gadot, 2003). Other studies describe organizational politics as a power play and influencing tactics that are designed to achieve the best results for the user (Kipnis et al., 1980).

This research proposes and tries to test the model that is the connection between leadership, politics, and performance. Thus, this study hopes to contribute knowledge, by examining the relationship between leadership and employee performance and discussing that politics as a variable between mediated organizations in this connection. 


\section{LITERATURE REVIEW}

\section{Transformational leadership, in-role performance, and organizational politics}

The connection between leadership, organizational politics and scientific performance roles has been extensively examined. This model is based on the idea of Ammeter et al. (2003) to build a political theory of leadership within the organization. This model examines the political perceptions of the organization as the intermediate variable in the relationship between leadership and performance. The rationale of this model is based on several LMX theories (Graen, 1976, Wang et.al., 2005), the theory of hope (Vroom, 1964) and the theory of social exchange (Blau, 1964). According to this theory, it is the leader's responsibility to create a reciprocal, fair, organizational atmosphere meeting the expectations and needs of individuals, managerial cadres, and overall organization. A balanced relationship between leaders and members is very important and fair treatment of individuals should be promoted as an organizational strategy. Improving fair relationships in a social exchange can reduce the level of organizational politics and positive impact on organizational performance.

This line of thought has been widely used in various studies. Ferris and Rowland (1981) argue that leader behavior affects employee job perception which then affects employee attitudes toward work and performance. Thus, employee perceptions in the workplace, such as political perceptions, may mediate between leadership and performance.

McKenzie Studies et al. (2001) examine the effect of transformational and transactional leadership on the performance of marketing personnel in an insurance company. Findings show that transformational leadership has more influence on performance rather than transactional leadership.

Bass (1985), using Multi-factor Leadership Questionnaire (MLQ), found a high correlation between transformational leadership styles and performance levels. This correlation is consistently higher than the positive correlation between the transactional leader style and organizational performance. According to Bass (1985) employees choose to identify tasks of leaders and organizations. These connection result in a basic agreement of employees with the norms they are obliged to do. Bass suggests that transformational leadership can make the identification and internalization of desired values contrary to transactional leadership to create the appropriate workforce.

Parry (2003) specifically examines leadership styles in public sector organizations and finds that the transformational leadership style has a positive effect on organizational innovation and effectiveness. Recent research, Wang et al., (2005) suggests the Leadership Members Exchange (LMX) of Graen (1976) as a good explanation for the mediating role of transformational leadership and organizational performance and OCB behavior. In many ways, LMX's theory is in line with Vroom (1964) and Blau (1964) which suggests a strong balance between managers and employees. According to this theory, good performance can be achieved only if there is reasonableness of expectations and when the social exchanges between managers and employees occur in the level of justice and equality. Wang et al., (2005) suggests that subordinates have expectations of the leader's role because subordinates do not want to be in a passive position. That is, in the relationship pattern, subordinates can play a role to refuse, accept or renegotiate the roles determined by the leader. The process is reciprocal based on justice and equality on exchange and hope and developed over time.

The connection between transformational leadership and performance measurement is positive and strong enough (Geyer and Steyrer, 1998; Lowe et al., 1996; McKenzie et al., 2001; Parry, 2003). It seems that organizations, especially in general, transformational leadership is more effective than transactional leadership. The skills of managers in 
transformational have the ability to support and educate employees and challenge them to develop themselves in doing the job.

Transformational leadership encourages employees to contribute to organizations that come out of personal motivation, challenge pressure or a desire to emulate leaders and position themselves as part of successful leaders. This idea is far from the idea of LMX theory as suggested by Graen (1976) and others. Nevertheless, it seems that transactional leadership has the ability to reinforce the effectiveness of performance (especially formal) that can be quantitatively quantified. Several studies have found that there is a significant connection between gratitude (one of the components of transactional leadership) and in-role performance (McKenzie et al 2001)

\section{Organizational Politics}

Studies that focus on organizational politics have taken a different approach. This study focuses primarily on employee perceptions of organizational politics (Ferris et al., 2004) as a strategic behavior designed to maximize personal interests and therefore conflict with the goals of the organization collectively or other interests. Block (1988), organizational politics, some of the basic patterns are negative. It said ... "if I say you are a very political person, you will regard it, both as an insult and as a mixed talent ..". Gdanz and Murray (1980) and Madison et al., (1980) observed that when people are asked to describe politics at work, there are usually selfish, manipulative, and not perceived positive activities.

The study that developed this concept (Andrews and Kacmar, 2001; Ferris and Kacmar, 1992; Vigoda-Gadot, 2003) finds that workplace politics is perceived as self-serving employee behavior to achieve personal gain, and sacrificing others who, sometimes conflicting with the goals and interests of the organization or work unit. This behavior is often associated with manipulation, slander, subversive, and illegitimate ways of excessive use of force to achieve one's goals (Kipnis et al., 1980).

Ferris et al. (2004) suggested the concept of Organizational Politic Perception Index (OPPI) as a good measure of organizational politics. In addition, Ferris and Kacmar (1992), argue that the higher the political perception in the eyes of an organizational member, the lower it gets in the eyes of others, about the level of equity. Ferris's research has used procedural justice theory to argue that organizational politics is related to Leadership Members Exchange (LMX) as well as the efficiency of human resource systems for the decision-making process. A lack of justice in this system is found to be a major cause of higher perception from organizational politics and hence organizational performance becomes inhibited. All of this research relies on the argument of Lewin at al., (1939), that people respond to their perceptions of the reality that exists and not the reality.

Politics in the organization must be understood in terms of what people perceive, not what is actually represented. Similarly, this study attempts to suggest that in many cases the perceptions of fairness reflect the political climate of the workplace and may also be related to formal and informal performance (Drory, 1993; Cropanzano et al., 1995). These ideas are widely replicated and supported in many previous studies (Ferris et al., 2004; Ferris and Kacmar, 1992; Vigoda-Gadot, 2003).

\section{RESEARCH METHOD AND HYPOTHESES}

The population of the research is employees of State-Owned Enterprises (SOEs) in the form of state-owned enterprises. The sample of the research was conducted on employees with the following characteristics: a) permanent employees of the company, b) have worked for at least one year. The sample size is 200 people at all levels of the organizational structure. 
Method of data analysis using Structural equation modeling analysis using AMOS.21. Variable measurements were performed using Interval scale between 1 (lowest score) to 5 (highest score). The hypothesis in this research formulated as many as 3 hypothesis as follows:

1. Transformational leadership has a positive and significant direct impact on Organizational Politics

2. Organizational politics have a positive and significant effect directly on in-role performance.

3. Transformational leadership has a positive and indirectly significant impact on in-role performance through Organizational Politics

\section{RESULTS AND DISCUSSION}

The test results of the validity of the indicators in each variable indicate that all indicators are valid because Average Variance Extract (AVE) shows the number of the variance of the indicators extracted by the latent variables developed. The acceptable value of the Average variance extract is a minimum of 0.50 . The minimum reliability value of an acceptable latent variable forming dimension is 0.7 .

Table 1

Evaluation of Criteria Goodness-of-Fit

\begin{tabular}{|l|c|c|l|}
\hline $\begin{array}{c}\text { Goodness of Fit } \\
\text { (GOF) Index }\end{array}$ & Cut-off Value & $\begin{array}{c}\text { Value on the } \\
\text { Research Model }\end{array}$ & \multicolumn{1}{|c|}{ Information } \\
\hline$X^{2}$ Chi-Square & Smaller & 128,648 & Not good \\
\hline Probabilitas & $\geq 0,05$ & 0,000 & Not good \\
\hline CMIN/DF & $\leq 2,00$ & 9,189 & Not good \\
\hline RMSEA & $\leq 0,08$ & 0,138 & Not good \\
\hline GFI & $\geq 0,90$ & 0,918 & Fit \\
\hline AGFI & $\geq 0,90$ & 0,837 & Marginal \\
\hline TLI & $\geq 0,90$ & 0,922 & Fit \\
\hline CFI & $\geq 0,90$ & 0,948 & Fit \\
\hline
\end{tabular}

The goodness of fit test results on the proposed standard model there are 3 that have met the criteria, namely :

a) GFI value of 0.918 is above 0.90 which means Fit

b) The TLI value of 0.922 is above 0.90 which means Fit

c) The CFI value generated from the calculation of 0.948 is good because it is more than 0.90 .

Hypothesis 1 accepted. The result of the statistical test on this hypothesis obtained p-value value of $0.041<0.05$ (cut of value), and its CR value of 2.046. That is, the influence of transformational leadership on in-role performance has a significant positive impact on the estimated coefficient value $(\beta)=0.332$. This finding is in line with other studies that found a more positive relationship (Wang et al., 2005).

Hypothesis 2 is accepted. The result of the statistical test to this hypothesis is obtained p-value equal to $0,047<0,05$ (cut of value), and CR value is 1,987. That is, the influence of organizational politics on the in-role performance has a positive and significant impact on the value of estimation coefficient $(\beta)=0.313$. This finding is inconsistent with 
Mintzberg's (1973) findings that the organization's politics allowed to undermine employee performance. This is in line with similar findings from other studies that have shown the negative effects of organizational politics, especially in public organizations (Vigoda-Gadot, 2003).

Hypothesis 3 was rejected, the result of the statistical test on this hypothesis obtained p-value value of 0,595>0, 05 (cut of value), and its $C R$ value equal to 0,530. That is, the influence of transformational leadership on in-role performance through organizational politics has a positive and insignificant impact on the value of estimation coefficient $(\beta)=$ 0,113 . Findings on the effects of organizational political mediation are not in line with research by Pillai et al., (1999) which states that the relationship between leadership and performance, to some extent, is indirect, but mediated. Trust, justice, and organizational politics are separate phenomena in the workplace (Andrews and Kacmar, 2001) but also strongly linked to each other, and one theory may be useful for understanding others (Ferris and Kacmar, 1992; Vigoda-Gadot, 2003)

\section{CONCLUSION}

Referring to result of analysis and discussion, hence can be drawn a conclusion as follows:

1. Transformational leadership positively and directly effects on in-role performance.

2. Organizational politics have a positive and significant effect directly on in-role performance.

3. Transformational leadership positively but indirectly impacts on in-role performance through organizational politics

In the next study can examine the influence of other variables that are likely to affect in-role performance such as transactional leadership and some other variables, but can use operational theory concepts from current and updated leadership and performance.

\section{REFERENCE}

Adams, G.L., et.al., (2002), "Perceptions of Organizational Politics: Additional thoughts, reactions, and multi-level issues", Research in Multi-Level Issues, Vol.1,pp.287-94.

Allen, R.W., Madison, D.L., Porter, L.W., Renwick, P.A. and Mayes, B.T. (1979), "Organizational politics tactics and characteristics of its actors", California Management Review, Vol.22, pp.77-78.

Ammeter, P.A., Prati, L.M., Douglas, C., Ferris, R.G., Buckley, R.M. 2003. Emotional Intelligence, Leadership Effectiveness, and Team Outcomes. The International Journal Of Organizational Analysis. Vol 11. No.1.

Andrews, M.C. and Kacmar, K.M. (2001), "Discriminating among organizational politics, justice, and support", Journal of Organizational Behavior, Vol.13, pp.751-96.

Bass, B (1985) Leadership and Performance Beyond Expectations. New York The Free Press

Bass, B.M., and Avolio, B.J. (1993), "Transformational leadership theory: a response to critiques". In Chemmers, M.M. and Ammons, R. (Eds), Leadership and Research: Perspectives and Direction, California Academic Press, Los Angeles, CA,pp.49-80.

Blake, J.J., and Mouton, J.S. (1964), The Managerial Grid, Gulf Publications, Houston, TX. 
Blau, P.M. (1964), Power and Exchange in Social Life, Wiley, New York, NY.

Block, P. (1988), The Empowered Manager: Positive Political Skill at Work, Jossey-Bass, San Francisco, CA.

Burns, J.M. (1978), Leadership, Harper \& Row, New York, NY.

Cropanzano, R.S., and Kacmar, K.M. (1995), Organizational Politics, Justice, and Support: Managing The Social Climate of The Workplace, Quorum Books, Westport, CT

Drory, A. (1993), "Perceived political climate and job attitudes", Organanizational Studies, Vol. 14, pp.59-71

Ferris, G.R. and Kacmar, K.M. (1992), "Perceprions of organizational politics", Journal of Management, Vol.8, pp.93-116.

Ferris GR, Ahearn KK, Hochwarter WA, Douglas C, Ammeter AP., 2004, Leader political skill and team performance. Jjournal Manage 30(3):309-27.

Gandz, J. and Murray, V.V. (1980), "The experience of workplace politics", Academy of Management Journal, Vol.23,pp.237-51.

Geyer, A.L., and Steyrer, J.M. (1998), "Transformational leadership and objectives performance in banks", Journal of Applied Psychology, Vol.47,pp.397-420.

Graen, G.B. (1976), "Role making processes within complex organization”, in Dunnette, M.D. (Ed), Handbook of Industrial and Organizational Psychology, Rand-McNally, Chicago, IL, pp.1201-45.

Kipnis, D., Schmidt, S.M. and Wilkinson, I. (1980)"Intreorganizational influence tactics: an exploration in getting one's way", Journal of Social Psychology, Vol.10,pp.271-99.

Lewin, K., Lippit, R. and White, R.K. (1939), "Patterns of Aggressive behavior of experimentally created social cultures, Journal of Social Psychology, Vol.10,pp.271-99.

Lowe, K.B., Kroeck, K.G. and Sivasubramaniam, N. (1996), "Effectiveness correlates of transformational and transactional leadership: a meta-analytic review of MLQ literature", Leadership Quarterly, Vol.7,pp.385-425.

McKenzie, S.B. Podssakoff, P.M. and Rich, G.A. (2001),'Transformational and transactional leadership and salesperson performance", Journal of Academy of Marketing Science, Vol.2, pp.115-34.

Madison, D.L., Allen, R.W., Porter, L.W., Renwick, P.A. and Mayes, B.T. (1980), "Organizational politics: an exploration of manager's perceptions”, Human Relations, Vol.33,pp.79-100.

Mintzberg, H. (1973), The nature of managerial work. New York, Harper Collins.

Parry, K.W. (2003), "Leadership, culture, and performance: the case of the New Zealand public sector", Journal of Change Management, Vol.4,pp.376-99.

Rowland K. And Ferris G., (1981) Research in Personnel and Human Resources Management. Vol. 2, pp. 35-80. Greenwich, CT: JAI Press 
Vigoda-Gadot, E. (2003), Developments in Organizational Politics, Edward Elgar Publishing, Cheltenham.

Vroom, V.H. (1964), Work and Motivation, Wiley, New York, NY.

Wang, H., Law, K.S., Hackett, R.D., Wang, D. and Chen, Z.X (2005), "Leader-member exchange as a mediator of the relationship between transformational leadership and followers performance and organizational citizenship behavior", Academy of Management Journal, Vol.48,pp.420-32. 